\title{
Instytucja referendum ogólnokrajowego na Ukrainie - aspekt normatywny
}

\begin{abstract}
Streszczenie: Celem artykułu jest przybliżenie rozwiązań prawnych regulujących instytucję referendum ogólnokrajowego na Ukrainie w okresie niepodległości. Z zamiarem jego osiągnięcia wykorzystana została metoda instytucjonalno-prawna. Analizie poddano przepisy poszczególnych aktów prawnych, w tym „Konstytucji Ukraińskiej Socjalistycznej Republiki Radzieckiej” z 1978 r., „Umowy konstytucyjnej pomiędzy Radą Najwyższą Ukrainy a Prezydentem Ukrainy” z 1995 r., „Konstytucji Ukrainy” z 1996 r., „Ustawy o ogólnoukraińskim i lokalnym referendum” z 1991 r., „Ustawy Ukrainy o Centralnej Komisji Wyborczej” z 2004 r. oraz „Ustawy Ukrainy o referendum ogólnoukraińskim” z 2012 roku. Uwaga została skupiona na regulacjach prawnych określających m.in. przedmiot referendum ogólnokrajowego, podmioty uprawnione do jego inicjowania i zarządzania, tryb powoływania komisji referendalnych, sposób ustalania wyników oraz skutki prawne referendum.

Ustawa o referendum ogólnoukraińskim z 2012 r., której przepisy były niejednokrotnie krytykowane przez środowiska eksperckie oraz część polityków, w kwietniu 2018 r., została uznana przez Sąd Konstytucyjny Ukrainy za niezgodną z konstytucją. W związku z tym obecnie brak jest na Ukrainie przepisów ustawowych regulujących zasady i tryb przeprowadzania referendum ogólnokrajowego. Ten stan rzeczy zmieniłoby przyjęcie któregoś z zarejestrowanych w parlamencie projektów. Jednak dotychczasowa praca deputowanych wskazuje, że Radzie Najwyższej VIII kadencji brakuje woli politycznej, aby przyjąć ustawę umożliwiającą obywatelom bezpośrednie decydowanie o ważnych sprawach życia państwowego.
\end{abstract}

Słowa kluczowe: referendum, Ukraina, konstytucja, ustawa

\section{Wstęp}

D ojęcie referendum jest określane m.in. jako „sposób bezpośredniego decydowania przez osoby uprawnione w drodze głosowania o ważnych sprawach życia państwowego lub określonego terytorium, będących przedmiotem głosowania" (Banaszak, Preisner, 1993, s. 139) ${ }^{1}$. W ukraińskiej literaturze przedmiotu jest definiowane jako „wyrażenie woli przez naród w drodze głosowania w ważnej sprawie państwowej lub społecznej” (Шляхтун, 2011, s. 636) oraz „głosowanie całej ludności państwa (ogólnopaństwowe referendum) lub pewnej jego części (referendum lokalne) w celu rozstrzygnięcia najważniejszych spraw życia państwowego i społecznego" (Основи, 2001, s. 115). W powyższym określeniu pojęcia referendum zostały jednocześnie wymienione jego rodzaje wyróżnione na podstawie kryterium zasięgu terytorialnego, a więc referendum lokalne oraz ogólnokrajowe, na którym to uwaga zostanie skoncentrowana w niniejszym artykule. W zależności od przyjętego kryterium wyróżnia się szereg innych

${ }^{1}$ Szerzej na temat pojęcia i istoty referendum zob. np. Podolak, 2014, s. 21-44. 
rodzajów referendów. I tak wedle materii referendum można wyróżnić referendum konstytucyjne - przeprowadzane w sytuacji uchwalania lub zmiany konstytucji, ustawodawcze - dotyczące zatwierdzania ustaw, administracyjne - przeprowadzane np. w sprawie nowego podziału terytorialnego państwa, a także finansowe - dotyczące np. kwestii samoopodatkowania się mieszkańców (Grabowska, 2009, s. 50)². Ze względu na kryterium obowiązku zarządzania (wymagalności) wyodrębnimy referendum obligatoryjne oraz fakultatywne, a stosując kryterium podmiotu inicjującego wymienimy referendum przeprowadzane z inicjatywy obywateli oraz z inicjatywy władz publicznych (Podolak, 2014, s. 83-87). Kryterium mocy prawnej pozwala wyróżnić referendum konstytutywne (wiążące) oraz opiniodawcze, zaś kryterium czasu przeprowadzenia - referendum ratyfikacyjne, którego celem jest zatwierdzenie podjętej przez parlament decyzji oraz referendum konsultacyjne, przeprowadzane przed podjęciem przez parlament decyzji ${ }^{3}$. Natomiast relacje pomiędzy rządzącymi a opozycją pozwalają jeszcze na wyodrębnienie referendum kontrolowanego - zarządzanego przez obóz rządzący, niekontrolowanego - zarządzanego przez siły opozycyjne, prohegemonicznego - skutkującego utrzymaniem lub umocnieniem władzy przez rządzących oraz antyhegemonicznego - skutkującego przejęciem władzy przez obóz opozycyjny (Antoszewski, 2003, s. 376; Musiał-Karg, 2008, s. 71-72).

Celem artykułu jest udzielnie odpowiedzi na następujące pytania badawcze: jakie normy prawne regulujące instytucję referendum ogólnokrajowego obowiązywały w okresie narodzin państwa ukraińskiego oraz jakie zmiany prawne dotyczące tej formy demokracji bezpośredniej następowały w kolejnych latach niepodległości, a w szczególności w wyniku zawarcia umowy konstytucyjnej w 1995 r., uchwalenia ustawy zasadniczej w 1996 r., uchwalenia ustawy o referendum ogólnokrajowym w 2012 r. oraz wydania orzeczenia przez Sąd Konstytucyjny Ukrainy w 2018 roku. Uwaga zostanie skoncentrowana na regulacjach prawnych określających m.in. pojęcie i przedmiot referendum ogólnokrajowego, podmioty uprawnione do jego inicjowania i zarządzania, tryb powoływania komisji referendalnych, proces ustalania wyników oraz skutki prawne rozstrzygnięcia referendalnego.

Głównym problemem badawczym jest więc ukazanie rozwiązań prawnych regulujących instytucję referendum ogólnokrajowego na Ukrainie w okresie niepodległości ${ }^{4}$. Z zamiarem osiągnięcia powyższego celu wykorzystana została metoda instytucjonalno-prawna. Badaniem zostały objęte przepisy poszczególnych aktów prawnych, w szczególności zaś normy „Konstytucji Ukraińskiej Socjalistycznej Republiki Radzieckiej” z 20 kwietnia 1978 r., „Ustawy o ogólnoukraińskim i lokalnym referendum” z 3 lipca

${ }^{2}$ M. Musiał-Karg obok referendum konstytucyjnego i ustawodawczego wyróżnia referendum problemowe, zaznaczając przy tym, że jest kategorią najszerszą i jest przeprowadzane w sprawach innych niż wymienione już dwa rodzaje referendów (Musiał-Karg, 2008, s. 78), zaś M. Podolak wyodrębnia referendum konstytucyjne, ustawodawcze, administracyjne oraz dotyczące spraw międzynarodowych (Podolak, 2014, s. 81-82).

${ }^{3}$ S. Grabowska ze względu na czas przeprowadzenia wyróżnia referendum ratyfikacyjne (post legem), którego przedmiotem jest akt prawny; referendum ante legem, określane też jako cząstkowe lub wstępne - poprzedzające uchwalenie lub złożenie aktu prawnego czy akceptację danego rozwiązania; a także referendum przeprowadzane w celu uchylenia obowiązującego aktu prawnego (Grabowska, 2009, s. 50-51).

${ }^{4}$ Artykuł uwzględnia stan prawny na dzień 6 lutego 2019 roku. 
1991 r., „Umowy konstytucyjnej pomiędzy Radą Najwyższą Ukrainy a Prezydentem Ukrainy o podstawowych zasadach organizacji i funkcjonowaniu władzy państwowej i samorządu terytorialnego na Ukrainie, zawartej na okres do uchwalenia nowej Konstytucji Ukrainy” z 8 czerwca 1995 r., Konstytucji Ukrainy z 28 czerwca 1996 r., „Ustawy Ukrainy o Centralnej Komisji Wyborczej” z 30 czerwca 2004 r. oraz „Ustawy Ukrainy o referendum ogólnoukraińskim" z 6 listopada 2012 roku.

\section{Regulacje konstytucyjne instytucji referendum na Ukrainie}

W warunkach niepodległej Ukrainy kwestie referendalne początkowo regulowała Konstytucja Ukraińskiej Socjalistycznej Republiki Radzieckiej (USRR) z 20 kwietnia 1978 roku$^{5}$. Art. 5 konstytucji stanowił: „Najważniejsze kwestie życia państwowego są poddawane dyskusji ogólnonarodowej oraz poddawane pod ogólnonarodowe głosowanie (referendum)" (Конституйія, 1978). Normy konstytucji przewidywały referendum ustawodawcze, zaś podmiotem uprawnionym do jego przeprowadzenia była Rada Najwyższa (RN) (art. 97). W wyniku nowelizacji ustawy zasadniczej USRR dokonywanych zarówno przed, jak i po ogłoszeniu niepodległości, zostały w niej zawarte i inne przepisy regulujące instytucję referendum. Znowelizowany 27 października 1989 r. art. 80 konstytucji stanowił: „Najważniejsze kwestie o znaczeniu republikańskim i lokalnym są rozwiązywane podczas sesji Rady Najwyższej Ukraińskiej RSR i terenowych Rad Deputowanych Ludowych lub poddawane są przez nie pod referenda" (Закон, 1989). Prawo zarządzania referendum ogólnonarodowego na terytorium republiki odniesiono do wyłącznej kompetencji RN (art. 97, ust. 18), zaś organizację przygotowań i jego przeprowadzenie powierzono Prezydium RN (art. 106, ust. 7). Dnia 5 lipca 1991 r. RN uchwaliła ustawę „O utworzeniu urzędu Prezydenta Ukraińskiej RSR i wniesieniu zmian oraz uzupełnień do Konstytucji (Ustawy Zasadniczej) Ukraińskiej RSR" (Закон, 1991a). W świetle przepisów uzupełnionej o art. 114-9 konstytucji, obywatele republiki uzyskali prawo wystąpienia z inicjatywą przeprowadzenia referendum ogólnokrajowego, którego przedmiotem byłoby usunięcie ze stanowiska prezydenta. Prawo zarządzenia referendum w tej materii, podobnie jak i w innych sprawach uzyskała RN. Powyższa norma obowiązywała jednak niedługo, gdyż została uchylona w wyniku przyjęcia noweli konstytucyjnej z 27 października 1992 r. (Закон, 1992).

Proces uchwalania nowej konstytucji Ukrainy znacznie się przedłużał, a przyczyną tego stanu rzeczy była rywalizacja między prezydentem a parlamentem o zakres przysługujących im uprawnień ${ }^{6}$. Dlatego też uchwalenie nowej konstytucji zostało poprze-

${ }^{5}$ Warto odnotować, iż chociaż konstytucje ZSRR z 1936 r. i 1977 r., a w ślad za nimi konstytucje USRR przewidywały możliwość przeprowadzania referendum, to jednak przez prawie cały okres państwa radzieckiego normy regulujące instytucję referendum pozostawały martwe. Jedyny raz odwołano się do nich w marcu 1991 roku, gdy zostało przeprowadzone referendum w sprawie zachowania odnowionego ZSRR (Ставнійчук, 2002, s. 293; Zieliński, 1996, s. 152-155). W okresie niepodległości Ukrainy referendum ogólnokrajowe było przeprowadzane dwukrotnie. Pierwszym razem 1 grudnia 1991 r., gdy Ukraińcy wypowiadali się wobec ogłoszonej przez RN niepodległości państwa ukraińskiego. Natomiast drugie odbyło się 16 kwietnia 2002 r., a jego celem było wzmocnienie pozycji ustrojowej prezydenta kosztem parlamentu (Moklak, 2006, s. 228-229).

${ }^{6}$ Na temat procesu konstytucyjnego na Ukrainie w latach 1991-1996 zob. Baluk, 2006, s. 91-98. 
dzone zawarciem porozumienia, stanowiącego dokument o charakterze Małej Konstytucji (Baluk, 2006, s. 95). Mianowicie w dniu 8 czerwca 1995 r. podpisano „Umowę konstytucyjną pomiędzy Radą Najwyższą Ukrainy a Prezydentem Ukrainy o podstawowych zasadach organizacji i funkcjonowaniu władzy państwowej i samorządu terytorialnego na Ukrainie zawartej na okres do uchwalenia nowej Konstytucji Ukrainy" (Конституиійний, 1995). Porozumienie znacznie wzmocniło pozycję ustrojową prezydenta kosztem parlamentu, a instrumentem który przekonał $\mathrm{RN}$ do jego zawarcia była groźba rozpisania referendum w sprawie wyrażenia zaufania dla parlamentu i prezydenta (Pietnoczka, 2018, s. 226). W wielu miejscach umowy uregulowano również kwestie referendalne. I tak art. 2 stanowił: „Całość władzy na Ukrainie należy do narodu. Naród jest jedynym źródłem władzy i realizuje ją jak bezpośrednio - w drodze referendum, tak i za pośrednictwem systemu organów państwowych oraz organów samorządu terytorialnego". Do kompetencji RN, podobnie jak w świetle konstytucji z 1978 r., odniesiono prawo zarządzania referendów ogólnoukraińskich, a ponadto ogłaszania ich wyników. Należy jednak podkreślić, że przepisy umowy wymieniły również prezydenta jako podmiot uprawniony do zarządzania referendów ogólnoukraińskich, stanowiąc przy tym, iż podstawy i tryb jego zarządzenia określa „Ustawa o ogólnoukraińskim i lokalnym referendum" (art. 26). Referendum mogło być rozpisane z inicjatywy RN lub co najmniej trzech milionów wyborców (art. 17, ust. 24). Sprawy związane z organizacją i trybem przeprowadzania referendów mogły być określone wyłącznie w drodze ustawy (art. 18, ust. 6). Strony umowy uzgodniły, że do czasu przyjęcia nowej konstytucji ani RN ani prezydent nie będą poddawać pod głosowanie w referendum ogólnoukraińskim żadnych spraw z wyjątkiem uzgodnionego przez obie strony tekstu nowej konstytucji (art. 61).

Dnia 28 czerwca 1996 r. RN uchwaliła wreszcie nową Konstytucję Ukrainy, a jej przyjęcie poprzedziła wyrażona przez prezydenta groźba rozwiązania parlamentu oraz przeprowadzenia referendum konstytucyjnego (Zieliński, 2007, s. 16-17). Jednocześnie została uchylona konstytucja z 20 kwietnia 1978 r. oraz porozumienie konstytucyjne zawarte między prezydentem a RN 7 czerwca 1995 r. (Toczek, 1999, s. 17). Przepisy dotyczące referendum zostały zawarte w rozdziale trzecim konstytucji zatytułowanym „Wybory. Referendum” (Конституиія, 1996, art. 69-70, art. 72-74), a ponadto w art. 85 rozdziału IV „Rada Najwyższa Ukrainy” oraz art. 106. rozdziału V „Prezydent Ukrainy”. W świetle norm ustawy zasadniczej naród wyraża swoją wolę „za pośrednictwem wyborów, referendum i innych form demokracji bezpośredniej" (art. 69). Prawo oddania głosu podczas referendum, tak samo jak podczas wyborów, zagwarantowano obywatelom Ukrainy, którzy najpóźniej w dniu głosowania ukończyli osiemnasty rok życia. Natomiast prawa głosu zostali pozbawieni obywatele uznani przez sąd za niezdolnych do czynności prawnych (art. 70).

W świetle konstytucji, podobnie jak przewidywała to umowa, referendum ogólnokrajowe może zarządzić $\mathrm{RN}$ lub prezydent, zaś prawo wystąpienia z inicjatywą jego przeprowadzenia przysługuje co najmniej trzem milionom obywateli, posiadającym prawo głosu. Jednocześnie musi zostać spełniony warunek dotyczący konieczności zebrania podpisów pod wnioskiem o przeprowadzenie referendum w co najmniej 2/3 obwodach Ukrainy. Ponadto w każdym z obwodów należy zebrać nie mniej niż po 100 tys. podpisów (art. 72). W art. 85 i art. 106, poświęconym odpowiednio kompetencjom parlamentu i prezydenta, określono $\mathrm{w}$ jakich sytuacjach zarządza referendum 
organ władzy ustawodawczej, zaś w jakich głowa państwa. Otóż RN została uprawniona do zarządzania referendum w sprawie zmiany terytorium Ukrainy, zaś prezydent $\mathrm{w}$ sprawie zmiany konstytucji, a ponadto w sytuacji gdy z wnioskiem o jego przeprowadzenie wystąpili obywatele. W art. 73-74 określono materię, która musi zostać poddana pod głosowanie w drodze referendum ogólnoukraińskiego oraz sprawy, które nie mogą stać się przedmiotem referendum. Otóż referendum obligatoryjne przeprowadza się w celu rozstrzygnięcia kwestii zmiany terytorium państwa, zaś przedmiotem referendum nie mogą być zagadnienia dotyczące podatków, budżetu i amnestii. Referendum obligatoryjne przeprowadzane jest ponadto w przypadku niektórych projektów zmian do konstytucji, a mianowicie projektów zakładających nowelizację przepisów rozdziału I konstytucji dotyczącego „zasad ogólnych”, rozdziału III poświęconego wyborom i referendum oraz rozdziału XIII regulującego kwestie zmiany konstytucji. Prawo wniesienia do RN projektów zakładających zmiany przepisów wymienionych rozdziałów konstytucji uzyskał prezydent oraz 2/3 konstytucyjnego składu RN. Następnie, gdy projekt zostanie zatwierdzony przez parlament większością $2 / 3$ składu, prezydent zarządza ogólnokrajowe referendum. Projekt zakładający zmiany przepisów rozdziałów I, III i XIII, a dotyczący tej samej sprawy może zostać powtórnie złożony jedynie do RN kolejnej kadencji (art. 156).

\section{Regulacje prawne instytucji referendum ogólnokrajowego w świetle „Ustawy o ogólnoukraińskim i lokalnym referendum” z 1991 r.}

W przeddzień ogłoszenia niepodległości Ukrainy, mianowicie w dniu 3 lipca 1991 r., RN uchwaliła „Ustawę o ogólnoukraińskim i lokalnym referendum”, która przez ponad dwadzieścia lat - do 2012 r. regulowała kwestie referendalne na Ukrainie (Закон, 1991b). Pojęcie referendum zdefiniowano jako „sposób przyjęcia przez obywateli Ukraińskiej SRR w drodze głosowania ustaw USSR oraz innych decyzji z zakresu ważnych kwestii o znaczeniu ogólnopaństwowym i lokalnym" (art. 1). Ustawodawca obok referendum ogólnoukraińskiego wyróżnił referendum Krymskiej Autonomicznej Socjalistycznej Republiki Radzieckiej (Krymskiej ASRR) oraz referendum lokalne przeprowadzane w granicach poszczególnych jednostek administracyjno-terytorialnych. Ustawom oraz innym decyzjom przyjętym w wyniku referendum ogólnokrajowego zapewniono wyższą moc prawną od aktów ustawodawczych RN USRR i RN Krymskiej ASRR, aktów prawnych prezydenta USSR, rządu USRR, najwyższych organów wykonawczych i zarządzających Krymskiej ASRR oraz terenowych Rad Deputowanych Ludowych. Decyzje podjęte podczas referendum nie potrzebowały dla swojej ważności zatwierdzenia przez jakikolwiek organ władzy państwowej (art. 1).

Przedmiotem ogólnoukraińskiego referendum w świetle przepisów ustawy mogło być zatwierdzenie konstytucji lub jej poszczególnych przepisów; przyjęcie, zmiana lub uchylenie ustaw oraz jej poszczególnych przepisów; przyjęcie decyzji określających zasadniczą treść konstytucji, ustaw oraz innych aktów prawnych (art. 3). Do spraw poddawanych pod głosowanie w referendum ogólnoukraińskim zaliczono te, które w świetle norm konstytucji mieszczą się w zakresie kompetencji republiki. Natomiast wyłącznie w wyniku referendum ogólnoukraińskiego mogła zostać podjęta decyzja w zakresie 
„realizacji prawa narodu Ukrainy do samookreślenia oraz wejścia Ukraińskiej SRR do państwowych struktur federacyjnych i konfederacyjnych lub wyjścia z nich" (art. 5). Pod głosowanie w referendum nie mogły natomiast zostać poddane sprawy należące do kompetencji sądów i prokuratury; pytania dotyczące amnestii i ułaskawienia; sprawy związane z użyciem przez organy republiki środków nadzwyczajnych w zakresie zagwarantowania porządku publicznego, zapewnienia ochrony zdrowia oraz bezpieczeństwa obywateli; a także sprawy dotyczące powoływania i odwoływania ze stanowiska funkcjonariuszy publicznych, znajdujące się $\mathrm{w}$ zakresie kompetencji RN, prezydenta oraz rządu (art. 5). Prawo udziału w referendum otrzymali obywatele USRR, którzy najpóźniej w dniu głosowania ukończyli 18 rok życia oraz byli zameldowani na pobyt stały na terytorium republiki. Tego prawa zostały natomiast pozbawione osoby chore psychicznie, uznane przez sąd za niezdolne do czynności prawnych oraz pozbawione wolności (art. 7).

Ustawa w ślad za konstytucją z 1978 r. stanowiła, że prawo zarządzenia referendum ogólnoukraińskego przysługuje jedynie $\mathrm{RN}$, zaś z inicjatywą jego przeprowadzenia mogą wystąpić obywatele republiki lub deputowani ludowi. W pierwszym wypadku wniosek o jego przeprowadzenie musiał uzyskać poparcie co najmniej 3 milionów obywateli posiadających prawo udziału w referendum i mógł dotyczyć kwestii zatwierdzenia lub uchylenia konstytucji oraz spraw związanych z rozwiązaniem RN lub odwołaniem ze stanowiska prezydenta. W drugim przypadku inicjatywa przeprowadzenia referendum musiała uzyskać poparcie co najmniej połowy składu RN, zaś pod głosowanie w nim mogły zostać poddane kwestie zatwierdzenia lub uchylenia konstytucji, a także innych aktów ustawodawczych republiki, ale z wyjątkiem przewidujących rozwiązanie RN lub odwołanie ze stanowiska prezydenta (art. 13). Od chwili otrzymania wniosku w sprawie przeprowadzenia referendum ogólnokrajowego, $\mathrm{RN}$ w ciągu miesiąca musiała zdecydować się na jedno z następujących rozstrzygnięć: podjąć decyzję o przeprowadzeniu referendum, odrzucić wniosek w sytuacji stwierdzenia „poważnych naruszeń” „Ustawy o ogólnoukraińskim i lokalnym referendum” lub rozwiązać kwestię, której dotyczył wniosek w sprawie referendum, ale bez jego przeprowadzania. W przypadku rozpatrywania wniosku dotyczącego przeprowadzenia referendum w sprawie odwołania ze stanowiska prezydenta, decyzja RN miała zostać podjęta większością $2 / 3$ jej składu (art. 21).

W celu przygotowania i przeprowadzenia referendum ogólnoukraińskiego tworzone były następujące komisje: Centralna Komisja ds. Referendum Ogólnoukraińskiego (CKWR), komisja Krymskiej ASSR ds. referendum ogólnokrajowego, obwodowe, rejonowe, miejskie, osiedlowe i wiejskie komisje referendalne oraz dzielnicowe komisje referendalne. Do momentu utworzenia CKWR jej zadania miała realizować Centralna Komisja Wyborcza ds. wyboru deputowanych ludowych (CWK). Ustawodawca umożliwił tworzenie komisji referendalnych w oparciu o istniejące komisje wyborcze (art. 24). CKWR mogła zostać utworzona najpóźniej półtora miesiąca przed dniem referendum, zaś w jej skład mieli wejść przewodniczący, jego zastępcy, sekretarz oraz 27 członków (art. 25). Uprawnienie tworzenia CKWR odniesiono do kompetencji RN, która powoływała jej skład spośród kandydatów zaproponowanych przez RN Krymskiej ASRR lub jej prezydium, rady obwodowe, Kijowską Radę Miejską i Sewastopolską Radę Miejską lub ich przewodniczących, a także organy partii politycznych, organizacji społecznych, 
ruchów masowych oraz referendalnych grup inicjatywnych (art. 15). Do zadań CKWR zaliczono rejestrację referendalnych grup inicjatywnych, przygotowywanie i przeprowadzanie referendum, kontrolę nad realizacją przepisów ustawy, określanie trybu wprowadzania zmian w składzie komisji referendalnych, dystrybucję środków pomiędzy poszczególne komisje, określanie wzorów dokumentów niezbędnych do przeprowadzenia referendum, ogłaszanie wyników referendum oraz rozpatrywanie podań i skarg dotyczących decyzji podejmowanych prze komisje referendalne (art. 26). Prawo do powołania komisji Krymskiej ARSR ds. referendum ogólnoukraińskiego przysługiwało RN Krymskiej ASRR lub jej prezydium, zaś prawo tworzenia komisji obwodowych, rejonowych, miejskich, osiedlowych i wiejskich należało do odpowiednich rad deputowanych lub ich przewodniczących. W skład tych komisji referendalnych miało wejść od 9 do 19 członków, zaś kandydatów mogły zgłaszać partie polityczne, organizacje społeczne, ruchy masowe, kolektywy pracownicze, zebrania obywateli oraz żołnierze poszczególnych jednostek wojskowych (art. 27). Natomiast powołanie dzielnicowych komisji referendalnych (DKR) należało do kompetencji rejonowych, miejskich, osiedlowych oraz wiejskich rad deputowanych, a także ich przewodniczących. W skład tych komisji miało wejść od 5-19 członków ${ }^{7}$, zaś kandydatów, podobnie jak w przypadku wyżej wymienionych komisji, mogły zgłaszać partie polityczne, organizacje społeczne, ruchy masowe, kolektywy pracownicze, zebrania obywateli i żołnierze poszczególnych jednostek wojskowych, a ponadto osiedlowe, wiejskie, uliczne, dzielnicowe i domowe komitety społeczne (art. 29).

W świetle art. 41 projekt ustawy (decyzja) poddany pod referendum uznawany był za przyjęty jeżeli udzieliła jemu poparcia większość głosujących. Ponadto musiał zostać spełniony warunek dotyczący frekwencji, która w przypadku większości spraw poddanych pod głosowanie nie mogła być niższa niż $50 \%$. W sytuacji gdy pod głosowanie poddano by kwestię rozwiązania RN lub odwołania ze stanowiska prezydenta, w referendum musiało wziąć udziału co najmniej $2 / 3$ uprawnionych do głosowania. W myśl art. 45 zmiana lub uchylenie ustawy oraz innych decyzji przyjętych podczas referendum mogło nastąpić w drodze referendum lub poprzez podjęcie decyzji przez RN większością 2/3 składu. Decyzja parlamentu musiała jednak następnie zostać zatwierdzona w drodze referendum, które powinno odbyć się w ciągu sześciu miesięcy od dnia wprowadzenia zmian lub uchylenia ustawy (decyzji). Ustawodawca dopuścił rozpisanie nowego referendum dotyczącego sprawy, która została już poddana pod głosowanie dopiero po upływie 5 lat od dnia przeprowadzenia referendum (art. 9.) Natomiast w przypadku gdy podczas głosowania referendalnego miało miejsce „rażące łamanie” przepisów ustawy, RN mogła zarządzić przeprowadzenie powtórnego referendum. W tej sytuacji dopuszczono możliwość powołania nowych komisji referendalnych (art. 43).

Ustawa przewidywała także przeprowadzanie referendum konsultacyjnego określonego również jako „badanie doradcze”, którego celem miało być „poznanie woli obywateli w sytuacji rozwiązywania ważnych spraw o znaczeniu ogólnopaństwowym i lokalnym" (art. 46). Wyniki referendum konsultacyjnego miałyby być uwzględniane podczas podejmowania decyzji przez organy władzy państwowej. W przypadku gdy projekty ustaw lub innych decyzji RN nie byłyby zgodne z wynikami badania dorad-

${ }^{7} \mathrm{~W}$ uzasadnionych sytuacjach właściwa rada deputowanych (lub jej przewodniczący) mogła podjąć decyzję o zwiększeniu lub zmniejszeniu liczby członków komisji (art. 29).. 
czego wówczas mogłyby zostać uchwalone przez RN wyłącznie większością 2/3 składu (art. 46). Przepisy ustawy stanowiły ponadto, że statusu badania doradczego nie mogą mieć badania opinii publicznej, które są przeprowadzane w trybie niezgodnym z normami ustawy lub dotyczą spraw, niemogących być przedmiotem referendum (art. 47). „Ustawa o ogólnoukraińskim i lokalnym referendum” była pięciokrotnie nowelizowana. Pierwszej dokonano 19 czerwca 1992 r., a więc prawie rok od ogłoszenia niepodległości państwa ukraińskiego (Закон, 1992b). Wśród wprowadzonych przez nowelę zmian należy wymienić zastąpienie określeń „Ukraińska SRR” i „Krymska ASRR” nazwami „Ukraina” i „Republika Krymska” (pkt 1). Jednak ta nowelizacja, podobnie jak i kolejne z 2001 r., 2010 r. oraz dwie z 2012 r. nie dokonały zmian w szczególności interesujących nas norm ustawy.

\section{Regulacje prawne instytucji referendum ogólnokrajowego $w$ świetle „Ustawy o referendum ogólnoukraińskim” z 2012 r.}

„Ustawa o ogólnoukraińskim i lokalnym referendum” obowiązywała do 2012 r., kiedy to parlament uchwalił nową ustawę regulującą kwestie referendalne, a mianowicie „Ustawę o referendum ogólnoukraińskim” (Закон, 2013). Z inicjatywą przyjęcia nowego aktu prawnego regulującego instytucję referendum ogólnokrajowego na Ukrainie wystąpił Dmytro Szpenow - deputowany z proprezydenckiej frakcji Partii Regionów. Ustawa została uchwalona w dniu 6 listopada 2012 roku, a jej przepisy znalazły akceptację 265 parlamentarzystów. Poparcia udzieliły jej frakcje większości parlamentarnej Partii Regionów, Komunistycznej Partii Ukrainy i Partii Ludowej, a ponadto deputowani grupy parlamentarnej „Reformy na rzecz przyszłości” oraz duża część deputowanych pozafrakcyjnych. Nie znalazła ona natomiast akceptacji w szeregach frakcji opozycyjnych: Koalicji Julii Tymoszenko - Ojczyzna oraz Koalicji „Nasza Ukraina - Ludowa Samoobrona" (Поіменне, 2012).

Przepisy ustawy określały pojęcie referendum ogólnoukraińskiego jako ,jedną z form demokracji bezpośredniej na Ukrainie, sposób bezpośredniej realizacji władzy przez Naród Ukraiński, polegający na przyjęciu (zatwierdzeniu) przez obywateli Ukrainy decyzji dotyczących kwestii o znaczeniu ogólnopaństwowym w drodze tajnego głosowania" (art. 1). Ustawodawca określając przedmiot referendum ogólnoukraińskiego wyróżnił jednocześnie cztery jego rodzaje: konstytucyjne, ratyfikacyjne, ustawodawcze oraz ogólne (art. 3). Przedmiotem referendum konstytucyjnego miało być zatwierdzenie nowej redakcji konstytucji, wprowadzenie zmian do konstytucji oraz uchylenie ustawy o wniesieniu zmian do konstytucji. Referendum ratyfikacyjne miało być przeprowadzane w przypadku zmiany terytorium Ukrainy, ustawodawcze - w sytuacji zatwierdzenia lub uchylenia ustawy o wprowadzeniu zmian do obowiązującej ustawy, zaś ogólne - w jakiejkolwiek sprawie z wyłączeniem tych, które nie mogą stać się przedmiotem referendum w myśl konstytucji (art. 3). W świetle art. 4 wyniki referendum ogólnoukraińskiego były wiążące.

Ustawa w ślad za konstytucją wymieniła podmioty, którym przysługuje prawo inicjowania referendum ogólnokrajowego oraz prawo jego zarządzania, a także określiła materię, która nie może być przedmiotem referendum. Ponadto stanowiła, że niemoż- 
liwe jest przeprowadzenie z inicjatywy ludowej referendum, którego przedmiotem byłaby zmiana terytorium Ukrainy. Ustawodawca uznał również, że nowa redakcja konstytucji oraz projekty ustaw poddawane pod głosowanie w referendum nie powinny uchylać lub ograniczać praw i wolności człowieka i obywatela oraz prowadzić do likwidacji niepodległości lub naruszenia integralności terytorialnej (art. 20, ust. 1-3). W myśl art. 21 referendum ogólnokrajowe nie mogło zostać zarządzone jak również przeprowadzone w warunkach obowiązywania stanu wojennego lub stanu nadzwyczajnego.

Prawo ogłoszenia początku „procesu ogólnoukraińskiego referendum” przysługiwało CWK. Z prawa tego miała już korzystać następnego dnia po opublikowaniu uchwały parlamentu lub dekretu prezydenta o zarządzeniu referendum. Ogólnoukraińskie referendum miało być przeprowadzane w ogólnopaństwowym okręgu referendalnym obejmującym terytorium Ukrainy oraz okręg zagraniczny (art. 37, ust. 1). W ramach okręgu ogólnopaństwowego CWK miała utworzyć 225 okręgów terytorialnych. Zadanie przygotowania i przeprowadzenia referendum spoczywało na CWK stanowiącej centralną komisję referendalną, okręgowych komisjach referendalnych (OKR) oraz dzielnicowych komisjach referendalnych (DKR). Kompetencje CWK w zakresie przygotowania i przeprowadzania referendum obejmowały terytorium Ukrainy oraz okręg zagraniczny, uprawnienia OKR granice terytorialnego okręgu referendalnego, zaś DKR terytorium dzielnicy referendalnej (art. 42, ust. 1-2).

Skład, tryb powołania, organizację działalności, kompetencje i finansowanie CWK oraz status prawny jej członków określa kilkunastokrotnie nowelizowana „Ustawa Ukrainy o Centralnej Komisji Wyborczej” z 30 czerwca 2004 roku (Закон, 2004). W myśl przepisów ustawy w skład CWK wchodzi siedemnastu członków, którzy są powoływani i odwoływani ze stanowiska przez RN Ukrainy na wniosek prezydenta ${ }^{8}$. Kadencja członków CWK wynosi 7 lat. Prezydent przygotowując wniosek zawierający kandydatury do składu CWK jest zobowiązany uwzględnić propozycje frakcji i grup parlamentarnych funkcjonujących w RN bieżącej kadencji (art. 6, ust. 1-3, ust. 8). Członkiem CWK może zostać osoba, która posiada obywatelstwo ukraińskie, ukończyła 25 rok życia, posiada prawo głosu, zamieszkuje na terytorium Ukrainy co najmniej od pięciu lat oraz włada językiem państwowym (art. 7, ust. 1). Przewodniczący CWK, jego dwaj zastępcy oraz sekretarz są wybierani w niejawnym głosowaniu podczas posiedzenia komisji (art. 9, ust. 1). Do kompetencji CWK należy m.in. zapewnienie obywatelom Ukrainy prawa udziału w referendach, stanie na straży przepisów konstytucji i ustaw określających zasady procesu referendalnego, zapewnienie jednakowego stosowania przepisów prawnych dotyczących przeprowadzenia referendum na terytorium całego państwa, opracowanie propozycji zmian do ustaw regulujących przeprowadzanie referendów, zwracanie się z wnioskiem do Sądu Konstytucyjnego Ukrainy (SK) w sprawie dokonania interpretacji przepisów konstytucji i ustaw regulujących przygotowanie i przeprowadzanie referendów (art. 17).

Tryb powoływania okręgowych i dzielnicowych komisji referendalnych określała „Ustawa Ukrainy o referendum ogólnoukraińskim”. W myśl jej przepisów komisje okręgowe były tworzone przez CWK najpóźniej czterdzieści dni przed dniem głosowania.

${ }^{8}$ Początkowo w skład CKW wchodziło piętnastu członków. Został on zwiększony do siedemnastu w wyniku nowelizacji ustawy dokonanej 18 września 2018 r. (Закон, 2018). 
W skład OKR miało wchodzić piętnaście osób - przewodniczący, zastępca przewodniczącego, sekretarz oraz pozostali członkowie komisji (art. 45, ust. 1 i ust. 3). Prawo zgłaszania kandydatur do OKR uzyskali przewodniczący RN Autonomicznej Republiki Krymu (ARK), przewodniczący rad obwodowych oraz przewodniczący miasta Kijowa i Sewastopola. W sytuacji gdyby uprawniony podmiot nie podał w wymaganym terminie kandydatur na członków komisji okręgowych wówczas takie prawo uzyskiwały właściwe administracje państwowe (art. 45, ust. 1 i 6 ). Przewodniczący, zastępca oraz sekretarz OKR mieli być wyłaniani w drodze losowania, którego zasady przeprowadzenia ustalała CWK (art. 45, ust. 4). Dzielnicowe komisje referendalne miały być tworzone przez odpowiednie komisje okręgowe najpóźniej dwadzieścia dni przed dniem przeprowadzenia referendum. W ich skład, tak samo jak w przypadku OKR, miał wchodzić przewodniczący, jego zastępca, sekretarz oraz pozostali członkowie - łącznie jednak, w odróżnieniu od OKR, jedenaście osób (art. 46, ust. 1-2)9. Prawo zgłaszania kandydatur do składu DKR przysługiwało komitetom wykonawczym rad wiejskich, osiedlowych, miejskich oraz rejonowych w miastach. Natomiast w przypadku gdyby powyższe organy nie funkcjonowały prawo zgłaszania kandydatur uzyskiwał przewodniczący wsi, osiedla, miasta i rejonu w mieście lub funkcjonariusz publiczny wykonujący ich kompetencje (art. 46, ust. 1). W sytuacji gdyby uprawniony podmiot nie podał kandydatur na członków DKR wówczas takie prawo uzyskiwały terenowe administracje państwowe. Przewodniczący, zastępca oraz sekretarz, tak samo jak w przypadku OKR, mieli być wyłaniani w drodze losowania (art. 46, ust. 5-6).

W świetle art. 82 głosowanie podczas referendum odbywało się od godz. 8.00 do 20.00. Po zamknięciu lokali referendalnych komisje dzielnicowe miały sporządzić protokół z podliczenia głosów, w którym zawarte byłyby informacje o liczbie kart do głosowania otrzymanych przez komisję; liczbie niewykorzystanych kart do głosowania; liczbie obywateli wniesionych do spisu uczestników referendum w obwodzie; liczbie osób, które otrzymały karty do głosowania; liczbie osób, które wzięły udział w głosowaniu; liczbie kart uznanych za nieważne; liczbie głosów, udzielających poparcia pytaniu referendalnemu; liczbie głosów nieudzielających poparcia pytaniu referendalnemu (art. 86, ust. 1-2). Następnie komisje dzielnicowe miały przekazywać dokumenty do okręgowych komisji referendalnych. Te z kolei na podstawie otrzymanych protokołów ustalałaby wyniki głosowania w terytorialnym okręgu referendalnym, postępując analogicznie jak miało to miejsce na szczeblu DKR ${ }^{10}$. Po sporządzeniu protokołu OKR miała niezwłocznie przekazać go do CWK (art. 91, ust. 10). Ta na podstawie przekazanych przez komisje okręgowe protokołów oraz protokołu CWK z podliczenia głosów w okręgu zagranicznym, ustanawiałaby w ciągu dziesięciu dni od dnia przeprowadzenia głosowania wyniki referendum (art. 93, ust. 1). Pytanie, które było przedmiotem referendum, uznawałoby się za przyjęte jeżeli uzyskałoby poparcie ponad połowy głosujących (art. 93, ust. 6). Oficjalne ogłoszenie wyników miało nastąpić podczas posiedzenia CWK. Natomiast najpóźniej na trzeci dzień od ich ogłoszenia, miały zostać opubliko-

${ }_{9} \mathrm{~W}$ przypadku dzielnic referendalnych, w których zamieszkuje nie więcej niż 50 osób posiadających prawo udziału w głosowaniu, możliwe było utworzenie DKR w składzie od trzech do pięciu osób (art. 46, ust. 2).

${ }^{10}$ Ustawodawca zobowiązał OKR do ustalenia wyników głosowania w ciągu pięciu dni od dnia przeprowadzenia referendum. 
wane w gazetach „Hołos Ukrajiny” i „Uriadowyj Kurier” oraz w innych środkach masowego przekazu (art. 94, ust. 2-3).

Wyniki referendum ogólnokrajowego przeprowadzonego z inicjatywy obywateli byłyby ostateczne i nie potrzebowałyby zatwierdzenia przez organ władzy państwowej (art. 95, ust. 1). Przyjęta w referendum nowa redakcja konstytucji, a także zatwierdzona ustawa o ratyfikacji umowy międzynarodowej dotyczącej zmiany terytorium państwa ukraińskiego nabierałaby mocy prawnej w dniu ogłoszenia przez CWK wyników referendum. W przypadku przyjętej podczas referendum ustawy, wchodziłaby ona w życie z dniem ogłoszenia wyników przez CWK lub w dniu określonym przez przepisy ustawy. Ustawa lub normy ustawy, poddane pod głosowanie w celu ich uchylenia traciłyby moc prawną z dniem ogłoszenia wyników referendum. Jednocześnie z tym dniem zaczęłyby obowiązywać normy konstytucji i ustaw, które były zmienione przez ustawę uchyloną podczas referendum (art. 95 ust. 2-5, art. 96, ust. 3). Powtórne referendum dotyczące tego samego zagadnienia nie mogło zostać przeprowadzone wcześniej niż po upływie roku od ogłoszenia wyników referendum (art. 4). Ustawa w ślad za konstytucją stanowiła, że w przypadku niezaakceptowania przez głosujących ustawy nowelizującej przepisy rozdziału I, III lub XIII konstytucji, powtórne zgłoszenie projektu noweli dotyczącej tego samego zagadnienia mogło nastąpić dopiero podczas kolejnej kadencji parlamentu (art. 96, ust. 2).

\section{Niekonstytucyjność „Ustawy o referendum ogólnoukraińskim” z 2012 r.}

Przepisy „Ustawy Ukrainy o referendum ogólnoukraińskim” z 2012 r. były niejednokrotnie poddawane krytyce zarówno przez ówczesnych opozycyjnych polityków, jak również i środowiska eksperckie. Switłana Kononczuk z Ukraińskiego Niezależnego Centrum Badań Politycznych (UNCPD) zaznaczała, że jej przyjęcie było podyktowane chęcią wzmocnienia władzy prezydenta, o czym miało świadczyć m.in. określenie przedmiotu referendum oraz tryb powoływania komisji (Конончук, 2012). Ekspertka podkreślała, że poprzednio ograniczenia dotyczące przedmiotu referendum mogła określać wyłącznie konstytucja, podczas gdy nowe przepisy zezwoliły na ograniczanie przedmiotu referendum także w drodze ustawy. Pod krytykę podpadł również sposób powoływania komisji referendalnych odbiegający od zasad powoływania komisji wyborczych, w przypadku których uprawnionymi podmiotami do zgłaszania kandydatur na członków komisji są frakcje parlamentarne oraz partie polityczne. W przypadku komisji referendalnych, o czym była mowa, prawo uzyskali m.in. przewodniczący RN ARK, przewodniczący rad obwodowych, przewodniczący Kijowa i Sewastopola oraz komitety wykonawcze rad wiejskich, osiedlowych, miejskich i rejonowych w miastach. Natomiast w sytuacji gdyby uprawniony podmiot nie podał kandydatur na członków OKR lub DKR wówczas takie prawo uzyskiwały właściwe administracje państwowe. Akceptacji nie znajdowały również przepisy określające kworum komisji referendalnych. Otóż w świetle art. 47, ust. 5 posiedzenie komisji uznano za prawomocne w sytuacji gdy uczestniczy w nim ponad połowa członków. Jednak już w dniu głosowania oraz podczas podliczania głosów nie określono takiego wymogu. Ustawodawca uznał, że wówczas ,posiedzenie komisji referendalnej jest pełnomocne niezależnie od liczby 
obecnych na nim członków komisji referendalnej” (art. 47, ust. 5) ${ }^{11}$. Krytyce poddane zostały również zapisy zezwalające na przyjęcie podczas referendum nowej konstytucji, co związane było z faktem, że przyjęcia ustawy zasadniczej w tym trybie nie przewiduje obowiązująca konstytucja (Конончук, 2012). Opozycja wśród celów przyjęcia nowej ustawy o referendum wskazywała na chęć obozu władzy wprowadzenia tą drogą zmian do konstytucji oraz doprowadzenia do przystąpienia Ukrainy do Unii Celnej tworzonej przez Rosję, Białoruś i Kazachstan (KCY, 2018). Chociaż w RN VII kadencji były podejmowane kroki zmierzające do uchylenia ustawy o referendum z 2012 r., to jednak opozycja okazała się zbyt słaba, aby osiągnąć ten cel.

Sytuacja uległa znacznej zmianie po Euromajdanie, gdy władza w państwie znalazła się w rękach oponentów politycznych byłego prezydenta W. Janukowycza. W grudniu 2014 r. 57 deputowanych reprezentujących cztery z sześciu partii, które pokonały próg wyborczy podczas elekcji parlamentarnej 2014 r., mianowicie Koalicji Petra Poroszenki (BPP), Frontu Ludowego (NF), Zjednoczenia „Samopomoc” oraz Ogónoukraińskiego Zjednoczenia „Ojczyzna” - zwróciło się do Sądu Konstytucyjnego Ukrainy w sprawie zbadania zgodności „Ustawy Ukrainy o referendum ogólnoukraińskim” z konstytucją. Po upływie ponad trzech lat, mianowicie 26 kwietnia 2018 r. SK wydał długo oczekiwane orzeczenie, którym uznał ustawę o referendum za niezgodną $\mathrm{z}$ ustawą zasadniczą. Za niezgodne z konstytucją zostały uznane przepisy ustawy, jak również sam tryb jej rozpatrywania oraz uchwalania (Рішення, 2018).

W czasie, gdy SK zajmował się badaniem zgodności ustawy z 2012 r. z konstytucją, w parlamencie w dniu 23 czerwca 2015 r. został zarejestrowany projekt „Ustawy o referendum ogólnoukraińskim" nr 2145a, wniesiony przez siedemnastu deputowanych z frakcji BPP, NF, Samopomocy i Ojczyzny oraz dwóch pozafrakcyjnych (Проекm, $2015)^{12}$. Inicjatorzy projektu w uzasadnieniu do niego zaznaczyli, że obowiązująca „Ustawa o referendum ogólnoukraińskim” jest sprzeczna z normami konstytucji oraz stwarza możliwość ,uchylenia lub wprowadzenia zmian do jej przepisów w niekonstytucyjny sposób i w konsekwencji stwarza niebezpieczeństwo likwidacji ustanowionego przez artykuł 1 Konstytucji Ukrainy demokratycznego reżimu politycznego" (Пояснювальна, 2015, s. 1). Po wydaniu przez SK orzeczenia o niezgodności „Ustawy o referendum ogólnoukraińskim" z konstytucją, a mianowicie 12 lipca 2018 r. w RN został zarejestrowany kolejny projekt ustawy regulującej instytucję referendum. Jest to projekt „Ustawy o referendum” $\mathrm{nr} 8590$ zgłoszony przez pozafrakcyjnego deputowanego Jewhenija Murajewa (Закон, 2018). W przeciwieństwie do projektu nr 2145a zawiera zapisy, które miałyby regulować nie tylko kwestie związane z przeprowadzaniem referendum ogólnokrajowego, ale również referendum lokalnego, a więc tak jak czyniła to ustawa z 1991 roku. Inicjator projektu, uzasadniając potrzebę jego przyjęcia, podkreślił, że w związku z brakiem podstawy prawnej do organizacji i przeprowadzenia ogólnokrajowego oraz lokalnego referendum, obywatele ukraińscy zostali pozbawieni możliwości realizacji określonego przez ustawę zasadniczą prawa (Пояснювальна, 2018).

${ }^{11}$ W świetle przepisów ustawy z 1991 r. posiedzenia komisji referendalnej były prawomocne, gdy uczestniczyło w nich co najmniej 2/3 członków komisji (art. 31).

${ }_{12}$ Wśród jego inicjatorów jest m.in. S. Zaliszczuk, O. Czernenko, M. Najjem, S. Łeszczenko, O. Syrojid, J. Soboliew. 


\section{Zakończenie}

Podsumowując należy podkreślić, że w okresie niepodległości kwestię instytucji referendum ogólnokrajowego regulowały trzy akty prawne rangi konstytucyjnej. W latach 1991-1995 była to wielokrotnie nowelizowana konstytucja z 20 kwietnia 1978 roku. W okresie od połowy 1995 r. do połowy 1996 r. „Umowa konstytucyjna pomiędzy Radą Najwyższą Ukrainy a Prezydentem Ukrainy”, zaś następnie Konstytucja Ukrainy uchwalona 28 czerwca 1996 roku. W świetle obowiązującej konstytucji prawo do zarządzania referendum ogólnokrajowego przysługuje prezydentowi oraz $\mathrm{RN}$, natomiast $\mathrm{z}$ inicjatywą jego przeprowadzenia mogą wystąpić obywatele, a ponadto $\mathrm{RN}$ w przypadku zmian rozdziału I, II i XIII konstytucji. Głowa państwa jest uprawniona do zarządzania referendum w sprawie zmiany konstytucji oraz w sytuacji gdy z inicjatywą jego przeprowadzenia wystąpili obywatele, natomiast parlamentowi przysługuje prawo zarządzania referendum w sprawie zmiany terytorium Ukrainy. Jeżeli powyższa materia, a więc zmiana terytorium państwa, jak również propozycja zmian do rozdziału I, III i XIII konstytucji stanie się przedmiotem referendum, wówczas otrzymuje ono charakter obligatoryjnego. Do zgłoszenia projektu ustawy zakładającej zmiany przepisów wyżej wymienionych rozdziałów ustawy zasadniczej został uprawniony prezydent oraz deputowani stanowiący co najmniej $2 / 3$ konstytucyjnego składu RN. Prezydent może zarządzić referendum dotyczące zmian przytoczonych rozdziałów konstytucji po uprzednim zaakceptowaniu projektu przez co najmniej 2/3 składu parlamentu. Należy także zaznaczyć, iż konstytucja określa katalog spraw, które nie mogą stać się przedmiotem głosowania referendalnego, a mianowicie kwestie dotyczące podatków, budżetu oraz amnestii.

Na poziomie ustawowym instytucję referendum ogólnokrajowego w latach 19912012 regulowała „Ustawa o ogólnoukraińskim i lokalnym referendum” z 3 lipca 1991 r., zaś w latach 2012-2018 „Ustawa Ukrainy o referendum ogólnoukraińskim” z 6 listopada 2012 roku. Po wydaniu przez SK w kwietniu 2018 r. orzeczenia o niekonstytucyjności „Ustawy o referendum ogólnoukraińskim” obecnie brak jest przepisów ustawowych, które regulowałyby zasady i tryb przeprowadzania referendum. Tym samym obywatele ukraińscy nie mają możliwości wyrażenia swojej woli w drodze głosowania referendalnego. Ten stan rzeczy zmieniłoby przyjęcie któregoś z zarejestrowanych w RN projektów ustaw, a więc projektu nr 2145a wniesionego przez przedstawicieli BPP, NF, Samopomocy i Ojczyzny oraz deputowanych pozafrakcyjnych lub projektu nr 8590 wniesionego przez pozafrakcyjnego J. Murajewa. Pierwszy z nich przewiduje uregulowanie instytucji referendum ogólnokrajowego, zaś drugi referendum ogólnokrajowego oraz lokalnego. Jednak bardzo długi czas rozpatrywania projektu nr 2145a zgłoszonego jeszcze w czerwcu 2015 r. przez deputowanych reprezentujących aż cztery frakcje parlamentarne, wskazuje jednoznacznie, że Radzie Najwyższej VIII kadencji brakuje woli politycznej, aby przyjąć ustawę umożliwiającą organizowanie i przeprowadzanie referendum ogólnokrajowego na Ukrainie i tym samym pozwalającą obywatelom na bezpośrednie decydowanie o istotnych sprawach życia państwowego.

Dotychczas Ukraińcy dwukrotnie uczestniczyli w referendum ogólnokrajowym - w referendum niepodległościowym 1 grudnia $1991 \mathrm{r}$. oraz referendum przeprowadzonym 16 kwietnia 2000 r., podczas którego poddano pod głosowanie propozycje zmian 
w konstytucji. Ukraina jest więc państwem, w którym rzadko korzysta się z tej formy demokracji bezpośredniej. Niemniej po wydaniu przez SK orzeczenia o niekonstytucyjności ustawy o referendum, ukraińscy obywatele są pozbawieni możliwości realizacji określonego przez konstytucję prawa. Dlatego też konieczne jest, aby parlament ukraiński zmienił obecny stan prawny i przyjął ustawę umożliwiającą obywatelom na wyrażanie swojej woli w ważnych sprawach państwowych w drodze referendum ogólnokrajowego.

\section{Bibliografia}

Antoszewski A. (2003), Referendum, w: Leksykon politologii wraz z Aneksem o: reformie samorzadowej, wyborach do sejmu, prezydenckich oraz gabinetach rzadowych, red. A. Antoszewski, R. Herbut, Wydawnictwo Atla 2, Wrocław.

Baluk W. (2006), Kształtowanie systemu partyjnego Ukrainy $w$ okresie transformacji ustrojowej (1987-2004), Oficyna Wydawnicza Arboretum, Wrocław.

Banaszak B., Preisner A. (1993), Prawo konstytucyjne. Wprowadzenie, Wydawnictwo Uniwersytetu Wrocławskiego, Wrocław.

Grabowska S. (2009), Formy demokracji bezpośredniej w wybranych państwach europejskich, Wydawnictwo Uniwersytetu Rzeszowskiego, Rzeszów.

Moklak J. (2006), Konstytucja i władza. U źródeł nowoczesnego parlamentaryzmu ukraińskiego, w: Ukraińskie tradycje parlamentarne, XIX-XXI wiek, red. J. Moklak, Wydawnictwo Historia Iagellonica, Kraków.

Musiał-Karg M. (2008), Referenda w państwach europejskich, Wydawnictwo Adam Marszałek, Toruń.

Pietnoczka P. (2018), Ewolucja pozycji ustrojowej instytucji prezydenta na Ukrainie, „Studia Politologiczne", vol. 47.

Podolak M. (2014), Instytucja referendum w wybranych państwach Europy Środkowej $i$ Wschodniej (1989-2012), Wydawnictwo Uniwersytet Marii Curie-Skłodowskiej, Lublin.

Toczek E. (1999), Wstęp, w: Konstytucja Ukrainy uchwalona na piątej sesji Rady Najwyższej Ukrainy 28 czerwca 1996 roku, wstęp i thumaczenie E. Toczek, Wydawnictwo Sejmowe, Warszawa.

Zieliński E. (1996), Referendum $w$ Rosji, w: Referendum $w$ Polsce $i w$ Europie Wschodniej, red. M. T. Staszewski, D. Waniek, Instytut Studiów Politycznych PAN, Warszawa.

Zieliński E. (2007), System konstytucyjny Ukrainy, Wydawnictwo Sejmowe, Warszawa.

Закон Украйни про внесення змін до статті 6 Закону Украӥни „Про Центральну виборчу комісію” від 18 вересня 2018 р., ВВР 2018, № 40, ст. 294.

Закон Украӥни про внесення змін і доповнень до Закону Украйнської РСР „Про всеукрайнський та місиеві референдуми від 19 червня 1992 р., ВВР 1992b, № 35, ст. 515.

Закон Украӥни про внесення змін і доповнень до статей 104, 114-5 і 114-9 Конституції (Основного Закону) Украӥни від 27 жовтня 1992, ВВР 1992, № 49, ст. 671.

Закон Украйни про всеукраӥнський референдум від 6 листопада 2012 р., ВВР 2013, № 44-45, ст. 634.

Закон України про Центральну виборчи комісію від 30 червня 2004 р., ВВР 2004, № 36, ст. 448.

Закон Украйнської Радянської Соџіалістичної Республіки про всеукраїнський та місиеві референдуми від 3 липня 1991 р., ВВР 1991b, № 33, ст. 443.

Закон Української Радянської Соиіалістичної Республіки про заснування поста Президента Української РСР і внесення змін та доповнень до Конституції (Основного Закону) Української РСР від 5 липня 1991 р., ВВР 1991а, № 33, ст. 445. 
Закон Украӥнської Радянської Соціалістичної Республіки про зміни і доповнення Конституції (Основного Закону) Української РСР від 27 жовтня 1989 р., ВВР 1989, № 45, ст. 624.

Конончук С., Народовладдя за викликом, 6.11.2012, „Українська правда”, https://www.pravda. com.ua/articles/2012/11/6/6976851/, 5.11.2018.

Конституиійний договір між Верховною Радою Украйни та Президентом України про основні засади організаиії та функиіонування державної влади і місиевого самоврядування в Украӥні на період до прийняття нової Конституиії Украӥни, „ВВР” 1995, № 18, ст. 133.

Конституція (Основний Закон) Української Радянської Соиіалістичної Республіки прийнята позачерговою сьомою сесією Верховної Ради Української РСР дев 'ятого скликання 20 квітня 1978 року, https://zakon.rada.gov.ua/laws/show/888-09/ed19780420, 29.10.2018.

Конституція України від 28 червня 1996 р., ВВР 1996, № 30, ст. 141.

КСУ оприлюднив рішення щзоо закону „Про всеукраїнський референдум”, 27.04.2018, „Уніан”, https://www.unian.ua/politics/10097966-ksu-oprilyudniv-rishennya-shchodo-zakonu-provseukrajinskiy-referendum.html, 5.11.2018.

Основи конституційного права Украӥни (2001), ред. В. Копєйчиков, Юрінком Інтер, Київ.

Поіменне голосування про проект Закону про всеукраӥнський референдум (№ 6278) - в иіломy (2012), http://w1.c1.rada.gov.ua/pls/radan_gs09/ns_arh_golos?g_id=3084906\&n_skl=6, 5.11.2018.

Пояснювальна записка до проекту Закону України „Про всеукраїнський референдум” (2015), http://w1.c1.rada.gov.ua/pls/zweb2/webproc4_1?pf3511=55689, 5.11.2018.

Пояснювальна записка до проекту Закону України „Про референдум” (2018), http://w1.c1.rada. gov.ua/pls/zweb2/webproc4_1?pf3511=64411, 21.01.2018.

Проект закону про всеукраїнський референдум № 2145а від 23 червня 2015 p. (2015), http://w1.c1. rada.gov.ua/pls/zweb2/webproc4_1?pf3511=55689, 5.11.2018.

Проект закону про референдум № 8590 від 12 липня 2018 p. (2018), http://w1.c1.rada.gov.ua/pls/ zweb2/webproc4_1?pf3511=64411, 21.01.2018.

Рішення Конституціийного Суду Украӥни у справі за конституційним подання 57 народних депутатів України щзодо відповідності Конституиіії України (конституційності) Закону Украӥни „Про всеукраїнський референдум” від 26 квітня 2018 р., № 4-p/2018.

Ставнійчук М. (2002), Теоретичні основи безпосереднього народовладдя, w: Конститучійне право України, ред. В. Погорілко, Наукова думка, Київ.

Шляхтун П. (2011), Референдум, w: Політична енциклопедія, голова редкол. Ю. Левенець, Парламентське видавництво, Київ.

\section{The institution of national referendum in Ukraine - normative aspect}

\section{Summary}

The aim of the article is to present legal solutions regulating the institution of national referendum in Ukraine during the period of independence. Achieving this aim required the application of an institutional and legal method. The provisions of particular legal acts have been analyzed, including "Constitution of the Ukrainian Soviet Socialist Republic" of 1978, "Constitutional Agreement between the Verkhovna Rada of Ukraine and the President of Ukraine" of 1995, "Constitution of Ukraine" of 1996, "Law on All-Ukrainian and Local Referendum" of 1991, "Law of Ukraine on Central Election Commission" of 2004, and "Law of Ukraine on All-Ukrainian Referendum" of 2012. Attention was focused on legal regulations specifying, among others, the subject of national referendum, entities entitled to initiate and manage a referendum, the procedure for the appointment of referendum commissions, the method of determining the results, and the legal effects of the referendum. 
The 2012 All-Ukrainian Referendum Act, the provisions of which have been criticized on several occasions by experts and some politicians, was declared unconstitutional by the Constitutional Court of Ukraine in April 2018. As a result, there are currently no statutory provisions in Ukraine governing the principles and procedure for holding a national referendum. This situation could be changed by adopting one of the drafts registered in parliament. However, the work of MPs so far indicates that the Verkhovna Rada of the eighth convocation lacks the political will to adopt a law enabling citizens to directly decide on important issues of state life.

Key words: referendum, Ukraine, constitution, law 